\title{
Ecologism in Interior Design
}

\author{
Ruizhou Liu \\ College of Art and Appareluages, Tianjin Polytechnic University, Tianjin 300384, China \\ E-mail: liuruizhouemail@126.com \\ Yunkai Xu \\ College of Science and technology and art, Jingdezhen Ceramic Institute, Jingdezhen 333001, China
}

\begin{abstract}
With the progress of our mankind, great changes have taken place in economy as well as our society, so have the natural environment and ecological system in which we live. Nowadays, we are faced with decreasing natural environment, forest, species, clean water, air and cultivable land. In addition, some urgent issues such as global warming, exhausted energy and widespread rubbish force us to reflect on our future life style. In this situation, interior designers are expected to introduce ecological ideas into their design to push it to a higher and advanced level, which will consequently promote the transformation of the employment of resources in architecture from the consumptive type to the recycled one.
\end{abstract}

Keywords: Interior, Design, Ecology

Interior environment is important to our human beings since most of us spend two thirds of our lives in it. According to ecologism, when creating comfortable living and working environment for people, pollution should be reduced to the greatest degree to keep the ecological balance of the whole world. Therefore, it seems particularly important to explore how to save natural resources to protect our environment, how to create the interior environment fir for our living as well as how to combine living, man and nature into an organic and harmonious whole. This article aims at exploring the application of ecologism in our modern interior design.

\section{Introduction}

\subsection{The Connotation of Eco-design}

According to Thoreau, a great American romantic ecological thinker, human beings should be adapted to nature instead of adapting it to us. A question raised by him---"'Is it proper to change our planet or to adapt ourselves to it in order to lead a safer life?"--- has caused a lot of attention and reflections. In The Economic System of Nature: The History of Ecologism written by Donald Worst, it was mentioned that "They have realized that one is enabling diseases to enter his body to destroy his soul once being out of touch with nature. Therefore, one will not do without touch with the ecosystem." Based on the above, we human beings are expected to reduce our grabs at natural resources and energy especially when taking our offspring into consideration.

\subsection{The Features of Eco-design}

Eco-design is a combination of ideas such as the human-oriented one, the economy and recycle of resources, the harmony between buildings and the surrounding ecological environment and so on. With human health being one of the most important features of eco-design, it should be attached much importance to in our design of ecological environment, sanitary conditions, three-dimensional afforestation, natural landscape, noise reduction, materials for architecture and decoration, air ventilation and so on. In addition, overall layout, building frame, the application of natural energy, energy-saving measures, afforestation system and living facilities and so on should also be considered in order to improve people's living environment and quality. Furthermore, in exterior design, efforts should be exerted to ensure the harmonious style of afforestation and buildings as well as supplementary but harmonious plants and to exert more functions of afforestation in the exterior environment to a deeper degree, such as heat-resistance, protection against wind, dust as well as noise and elimination of poisonous substances, viruses and bacteria. In terms of the construction of buildings, the requests in natural ecology and social ecology should be both taken into account to emphasize energy saving and dwellers' requests for their natural space and personal communication.

\section{Eco-elements in Interior Design}

\subsection{Saving Natural Resources}

Natural resources are composed of self-born energy, reproducible resources and irreproducible resources. Self-born energy refers to the inexhaustible one such as solar energy, wind energy, water energy, geothermal energy and biological 
energy and so on. Different from it, some resources such as coal, electricity and water cannot be self-born or reproduced, hence decreasing day by day. However, reproducible resources, such as fishes and trees, will survive with their reproduction as long as we make reasonable use of them. Accordingly, in our eco-design, self-born energy and irreproducible resources should be saved and recycled and reproducible resources be used at a low rate. For example, more solar energy should be applied to heating and cooking by fixing solar energy facilities in the areas enjoying over 2500 hours' sunshine in a year; different water should be used for different purposes (system A offers drinking water and system B offers recycled water for other use, such as sweeping the floor, watering flowers, cleaning cars and so on; energy-saving lights should be used as well.

\subsection{Using Environmental Protection Building Materials}

With a tendency for "luxury”, “novelty", “fashion” and "style” in modern interior design, an excessive amount of stainless steel, aluminium boards, copper strings, plastics, glass, polished stones and marbles have been used, hence having negative influences on the sustainable development of construction industry. According to eco-design, more natural materials such as wood, stone, vine, bamboo and fabrics should be employed in our interior design to pursue a simple, concise and comfortable atmosphere.

In addition, a lot of artificial chemicals with some harmful substances, such as formaldehyde, benzene and some volatile organic compounds, have been employed in modern interior design. Besides their offensive flavors, they also tend to cause some health problems such as headache, sore throats, weariness.

Meanwhile, with the pace of living quickens, our interior design is updated from time to time. Hence a lot of removed building materials are piled into a pollution source in our environment. If not dealt with in time, our eco-system and environment will get destroyed in a short time and we will face more trouble in environmental treatment.

Therefore, with the reasonable use of environmental protection building materials, such as non-toxic coating, reproducible wallpaper, less pollution will be produced to the surrounding environment as well as people in the production and application courses. In addition, the removed materials are easy to be degraded and recycled into new products.

\subsection{Taking Climate and Location into Consideration}

By using an excessive amount of artificial lighting and air-conditioning, the communication between man and nature has been broken, hence causing a waste of energy as well as harm to human health. Therefore, climate and location elements should be taken into consideration in eco-design. Because some elements, such as direction, layout and utilization of space, landform and terrain, influence heat preservation, insulation against heat, sunshine and ventilation in our houses, we should try to make use of natural heat and cool air to improve the air conditions indoors.

A reasonable direction should come first in eco-design, which is closely related to sunshine, heat accumulation and ventilation. With China lying in the middle and low-latitude zones of the Northern Hemisphere, houses facing south here will be protected against wind and enjoy sunshine in winter and enjoy breeze and be protected against sunshine in summer. Generally speaking, a series of elements are related to the direction of buildings, such as geographical latitude, geographical environment, local climate features, the conditions of building lots and so on. When defining a favorable direction or an optimal direction range, sunshine and wind are the most important standards. With different optimal direction ranges in different cities, a reasonable direction should be chosen to gain more sunshine. In addition, the ultraviolet radiation in sunshine, helping to kill bacteria and improve air conditions, also varies in intensity in different directions. During the daytime, the ultraviolet radiation reaches its peak intensity around midday and comes to the lowest point just after sunrise and before sunset. It is shown that houses facing south, southeast and southwest receive the greatest amount of ultraviolet radiation in winter, those facing east and west only receive half of the greatest amount and those facing northeast, northwest and north receive only one third of the greatest amount. Therefore, taking ultraviolet radiation into our consideration, the direction range from $45^{\circ}$ east of due south to $45^{\circ}$ west of due south is the best one. Besides, the dominant wind direction is also important due to its influence on the heat exhaustion in winter and ventilation in summer. In the northern part of China, houses should not be built facing the dominant wind direction in winter to protect against cold wind. For example, in Tianjin, with its dominant wind directions in winter being north and northwest wind, the direction range from $60^{\circ}$ southeast of due north to $60^{\circ}$ west of due south is the best for the houses there. However, in the southern part of China, it is particularly important to gain favorable ventilation conditions. Therefore, their houses should be built with an angel of incidence less than $45^{\circ}$ with the dominant wind direction in summer in order to get more draught.

Similarly, the layout of spce cannot be neglected in eco-design due to its influence on human health. As a place for rest, sleep and clothes storage, the bedroom should be designed to be quiet and private. Nowadays, with most people busy with studying and working in the daytime, it makes little difference for a bedroom to face south or north, to have or have no direct sunshine in eco-design. Instead, the sitting room now serves as the major space for most of our activities at home, especially for office workers in the two rest days, for the old and babies, and for students in winter and 
summer vacations, hence demanding for large space and sufficient sunshine. Therefore, the sitting room is designed much larger than the bedroom in our modern interior design. If the sitting room faces south, a lot of energy will be saved with the great amount of sunshine in the daytime.

In addition, the utilization of space should be taken into consideration. Only with favorable ventilation conditions and broad field of view will fewer bacteria grow in corners and the dwellers be in good mood. Besides, despite of the goal of “creating comfortable and elegant living environment”, moderate consumption should be proposed in our eco-design. In this aspect, transitional space, such as the hallway and the corridor, cannot be too large. Besides, from the perspective of practicality, enough storage space should be created in eco-design.

\subsection{Expanding and Employing Afforestation}

By expanding and employing more afforestation, the shortage of green areas will be made up and the interior afforestation, together with ventilation and sunshine, will help to improve the separation between the interior space and the outside natural world. Besides, the soil-free cultivation technology also makes it possible to create green areas on our balconies, windowsills, corners and roofs.

\section{Conclusion}

Nowadays, eco-design is still a new, leading concept for interior design. With our stronger sense of environmental protection, we begin to shift our attention to this issue from public areas to our own possessions. With the development of our economy and the improvement of our living standard, eco-design will play an important role in the future society, in which more importance should be put to health, comfort, convenience and efficiency. If combining man, nature and living into an organic whole, we'll be lucky enough to have a sunbath, breeze and humid air without stepping out of our houses. In the modern times, eco-design will help us to revive the free and comfortable lives of our ancestors in the beautiful natural world in our own houses.

\section{References}

China Architecture \& Building Press .(1999). Energy Saving in Building.

Xu, Zhanfa. (1998). A Practical Handbook of Energy Saving Technologies in Building. China Machine Press. 